\title{
クモ膜下出血後に発生する正常压水頭症
}

一特にその病態への栘行陟に抄ける頭䓝内圧上脳血流の变化一

\author{
林実・古林 秀則・宗本 滋・東 壮太郎 \\ 能崎 純一・半田 裕二・山本信二郎・前田 敏男*

\section{Changes of Intracranial Pressure and Cerebral Blood Flow in Patients with Normal Pressure Hydrocephalus after Subarachnoid Hemorrhage}

\author{
Minoru Hayashi, Hidenori Kobayashi, Shigeru Munemoto, Sotaro Higashi, \\ Jun-Ighi Nozaki, Yuji Handa, Shinjiro Yamamoto and Toshio Maeda* \\ Department of Neurosurgery, University of Kanazawa, Kanazawa 920 \\ *Department of Nuclear Medicine, Lniversity of Kanazawa
}

\begin{abstract}
Summary
Normal pressure hydrocephalus (NPH) often complicates after the rupture of intracranial aneurysms (NPH developed in $17.4 \%$ of our series). To clarify the pathophysiology and indication of shunting, intracranial pressure (ICP), cerebral blood flow (CBF) and radio nuclide cisternography were studied in patients who developed hydrocephalus after subarachnoid hemorrhage ( $\mathrm{SAH}$ ).

Patients developing hydrocephalus after SAH were divided into three stages, i.e., the acute stage (within one week after SAH), pre-NPH state and NPH state. Pre-NPH and NPH state patients had enlarged ventricles and periventricular lucency on CT scans and delayd absorption of CSF and/or complete block of the subarachnoid space with ventricular filling on cisternography. The ICP base-line in continuous ICP recordings was at a level of less than $15 \mathrm{mmHg}$ in NPH patients, and at a level of more than $15 \mathrm{mmHg}$ in pre-NPH statc patients. ICP curves in the acute stage of patients who were drowsy after $\mathrm{SAH}$ showed pressure variations superimposed on an increased ICP basc-line. The prcssure variations wcrc recurring increases in ICP in the range of $20 \sim 40 \mathrm{mmHg}$ and resembled the $\mathrm{B}$ - and $\mathrm{C}$-waves of Lundberg. ICP curves in pre-NPH and $\mathrm{XPH}$ state paticnts showed plateau waves or B-waves. The platcau waves seen in these patients usually ranged between $30 \sim 50 \mathrm{mmHg}$ and lasted for $5 \sim 10$ minutes, i.e., the waves were smaller and briefer than those seen with increased intracranial pressuer from brain tumors. A few NPH patients showed a continuously low and fat ICP curve. ICP in these patients wcre recorded more than six months after SAH.

Changes in CBF wcre analyscd. Mean values of $42.9 \mathrm{~m} / 100 \mathrm{gr} / \mathrm{min}$ were obtained in acute stage patients. Pre-NPH and NPH state patients showed flows of 35.1 and $28.7 \mathrm{ml} / 100 \mathrm{gr} / \mathrm{min}$, respectively. Marked reduction in CBF (23.8 $\mathrm{m} / 100 \mathrm{gr} / \mathrm{min})$ was found in NPH patients with the low and flat ICP pattern. l'hus, CBF was markedly reduccd in patients with NPH in spite of the lowered ICP.

The shunting procedure brought about remarkable recovery in pre-NPH and NPH state patients who showed pressure waves in continuous ICP recordings and a CBF of over $25 \mathrm{ml} / 100 \mathrm{gr} / \mathrm{min}$.
\end{abstract}

Key words: subarachnoid hemorrhage, normal pressure hydrocephalus, intracranial pressure, cerebral blood flow

金沢大学脳神経外科

* 金沢大学核医学科

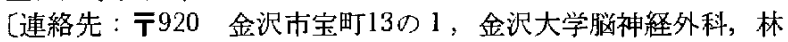

1980年 7月 1 日 受稿 


\section{Iはじめ}

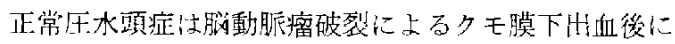
しばしばみられる合併症の1つであるが、この病態への 移行孝早期に知り，適切公治療を加えることは患者の早 期回復，さらには社会復帰索早めるといら点加ら重要て ある。このため近年, 正常圧水頭症の診断に関しては,

より早期にこれを行抢らとする傾向にありこ机には CIscan，頭盖队圧連続测定の普及が大きく貢献してい ると思われる。

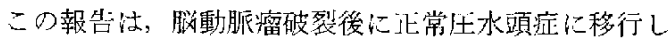
たあるいは移行しつつある掠例について，主として頭 盍内圧锶態, CT scan, 脑血流の面加ら検討老行ったる のである。

\section{II 症例と方法}

脳動脈瘤破裂によるク膜下出抓後に正常圧水頭症に 移行した43例(術前24例, 術後19例)について検幸した。 全例に頭蓋内圧の連続测定, CT scan, cisternography が 行われ，正常压水頭症診断のたかの資料とした。一部症

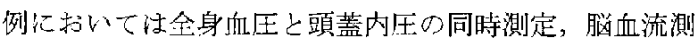
定が行われ，病態の検索に資した。

頭蓋内生の測定江左側脳空前何に外径 $3 \mathrm{~mm}$ のボリ工 チレンチューブ在留置し，脳室液苦接 pressure transducer (日本光電製 MPU-0.5) に導き，ポリレコーダー (東吏電波製 CDR-12A) に接続して記録した。

全身血圧は大腿動脈にポリェチレンチェーブを留置し て記録した。

一部症例に妨いて頭蓋内圧変動の詳細を検菜するため に脳波計（口林光電製 ME-135D）应用い，頭蓋内圧， 全身血圧，頭蓋内压と全身血压との差，心電図，心拍 数，呼吸，脳波紊ポリグラフィにより記録した。

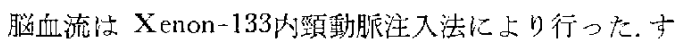

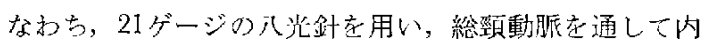
頚動脈に留置し， $2 \mathrm{ml}$ の生理食塩水に溶解した ${ }^{133} \mathrm{Xe}$ $185 \sim 296 \mathrm{MBq}(5 \sim 8 \mathrm{mCi})$ t 1 秒以内の速度で注入し た。测定とデー夕処理にはガンマカメラと核矤学データ 処理装䈯を用いた。局所媨血流を $32 \times 32$ matrix（領域の） 大きさ注10 $\mathrm{mm} \times 10 \mathrm{~mm}$ ) ごとに height over area 法で 算出した.

Cisternography स $^{111}$ In-DTPA $18.5 \sim 37 \mathrm{MBq}(0.5 \sim$ $1 \mathrm{mCi}$ を腰椎穿刺により髄腔内に注入し，2，5〜6， 24，48時間後にガンマカメラ文用いて，頭部各方向の scintigram をとり検索した。

CT scan EMI-1010を用い行った。
让常厓水頭淽の判定は出血後 1 週间以上索释過し，頡

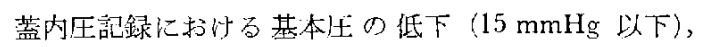
Cl'scan に括活马脳室桩大上 periventricular lucency 認め， cisternographyでアイソトープの長時間停滞ある

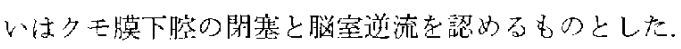

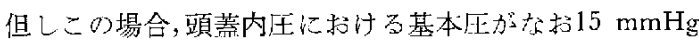
以上の高值示示舟のは，正常圧水頭装準備状態として 一灾区別し検討した.

\section{III 結 果}

\section{1. 脳動脈㿇破裂後における shunt 手術の頻度}

1976年1月加ら1979年12月までに入院した破裂脳動脈 瘤は247例あり，正常圧水頭症，あるいはその準備状態の 診断のもとに shunt 手術省行った马のは43例 (17.4\%) であった。

\section{2. 急性期頭舊内圧方進状態加正正常圧水頭症への移行}

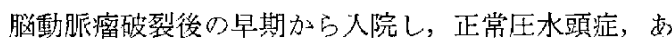
るいはその淮诵状热に移行するまで䫓蓋内圧を連続的に 記録しえた症例が3例女る。これらの症例のらら2例は 状態の改善が得られず，家族が手術を希望しなかったす のであり，1例は記録中血管攀縮が発生し，その宽解を 待っていた特期に発牛した。これらの症例に打りる頭蓋 内生の稰過は，正常压水頭症の病態を考える上で興味あ ると思われるので呈示する

症例 1 ：52才，女性，前交通動脈瘤

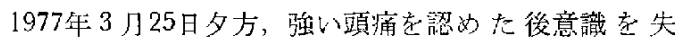
心, 近くの病院一入院し，出血 7 日日に当科一転科 L た. 入院時 Hunt 上Hess $の$ 重症度分類 ${ }^{8)}$ で Grade IV 状悲ですりこのとき施行された CT scan では著しい

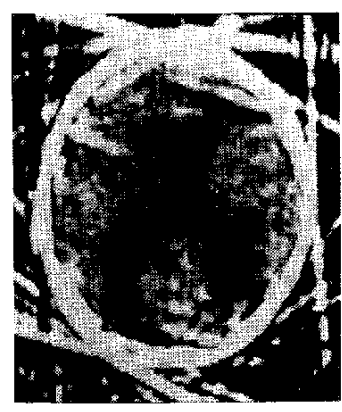

(A)

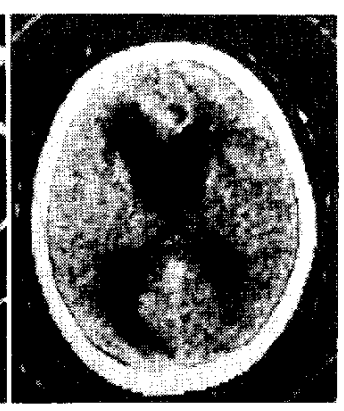

(B)
Fig. 1 52-year-old woman, anterior communicating aneurysm. CT scans 7 days (A) and 15 days (B) after the subarachnoid hemorrhage. (A) shows enlarged ventricles, whereas (B) shows cnlarged ventricles as well as periventricular lucency. 

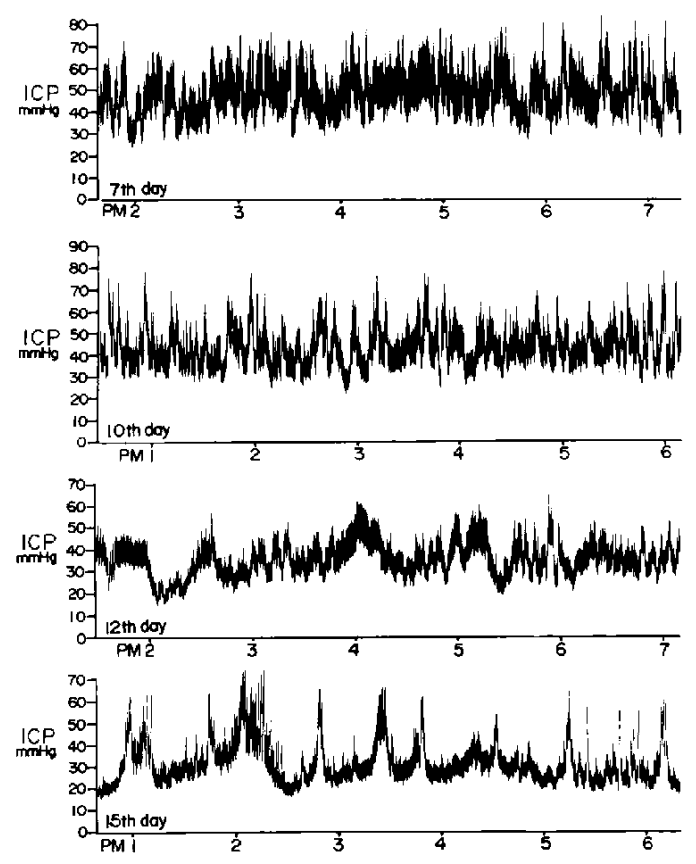

Fig. 2 ICP recording of the same patient as in Fig. 1. High levels of ICP with marked fluctuations are seen on the 7 th and 10 th day. They were replaced by a low level ICP with plateau waves on the 15 th day. CT scan at this time showed enlarged ventricles with periventricular lucency.

脳室系の拡大が認方られた(Fig. 1(A))．递血管写では前

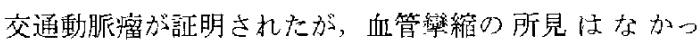
た，意識状態が悪く，家族は手術を希㕵しなかったので 頭蓋内圧記録のみを行い経過をみた。その記録が Fig. 2 に示される. 出血10日目までは30 $\mathrm{mmHg}$ 以上の高い頭

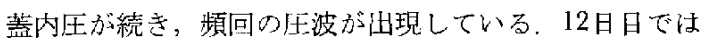
間歇的 $220 \mathrm{mmHg}$ 以下に下降寸る時期为两られ，15日 目には基本压は明らかに20 $\mathrm{mmHg}$ 前後をで下降し，代 わって間䟜的纪60 70 $\mathrm{mmHg}$ まで上异寸るプラトウ波 様圧波の出現をみた。出血15日目における CTscan仿, 脳葟系の㹡大の進行と periventricular lucency を認めて いる (Fig. 1(B)).

本例は出血18 日目に動脈瘤クリッピングと shunt 手術 が行打机，息く回復しえた。

症例 $2: 58$ 才, 男性, 左中大㮁動脈瘤

1978年 9 月13日，意識消失と右片麻㾝が出現し，3 日 後に当科入入院した，入院時 Grade IV の状態であり， 右完全片麻凄が認好られた，CT scanでは一部脑室内一

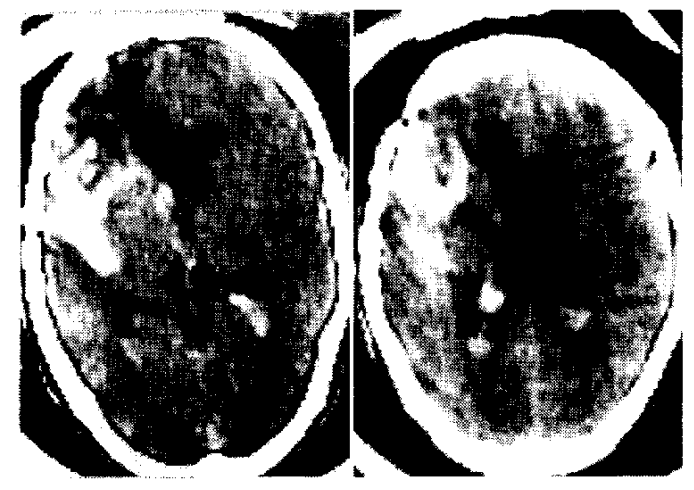

(A)

(B)

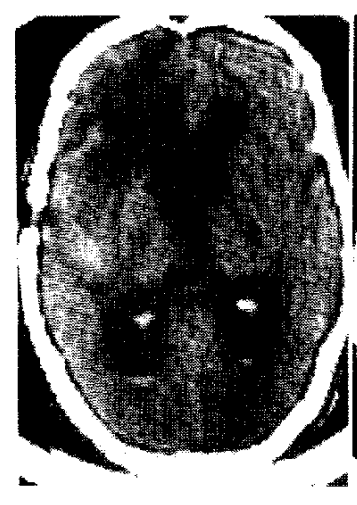

(C)

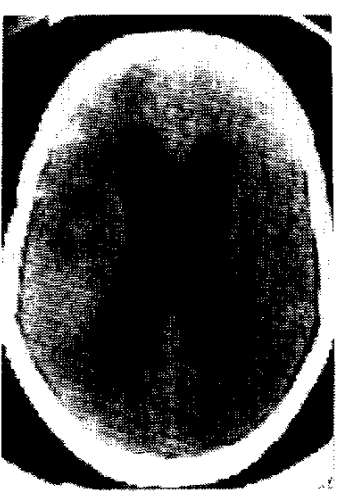

(D)
Fig. 3 58-year-old man, left middle cerebral artery aneurysm. CT scans 3 days $(A, B)$ and 15 days $(C$, D) after the subarachnoid hemorrhage. (A) and (B) show a hematoma on the left front-temporal area with mild dilatation of ventricles. (C) and (D) show enlarged ventricles with periventricular lucency.

穿破した左前頭一側頭莱㨫内血腫索認めた（Fig. $3(\mathrm{~A})$ ，

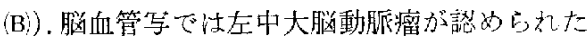

本例性意諳状態が悪く，右完全片麻痖があり，家族は

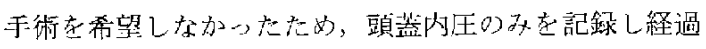
を东た，Fig. 4がこのときの記録である.山血5日月で 注基本圧は20 $\mathrm{mm} H \mathrm{~g}$ 前後上上升して扔り, こ扎化重胃 ナ石頻回の頭蓋内圧変動加出現している．11日目に至 り, 基本压は下降傾们を示し, 頭苗内恃変動の出現も少 なくなっている，15日目の記録では基本庄は10 $\mathrm{mmHg}$ 前後と汇常範囲内に下降しているが，間歇的にB波様顽 㥺内压変動が群発している。この時期のCT scanがFig $3(\mathrm{C}) ，(\mathrm{D})$ に示さ扎万。急性期における high density

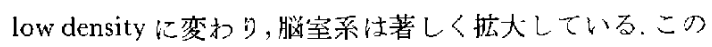
時期红 cisternography が行われたが, 宼型的なobstructive communicating hydrocephalus の所胃党得た. 


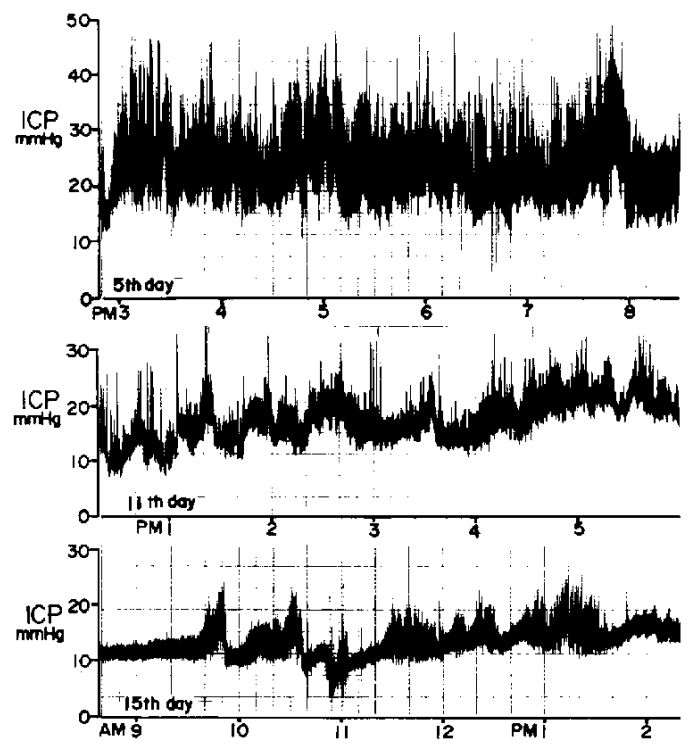

Fig. 4 ICP recording of the same pationt as in Fig. 3. High levels of ICP with marked fuctuations were registered on the 5 th day. Gradual decrease in ICP was scen on the 11 th day and low level ICP with pressure waves was recorded on the 15 th day. CT scan on this day showed markedly dilated ventricles.

以上の経過上り，本例は15日日纪すで正常圧水頭症に 移䘕したとみることができる。

出血26口目, 動脈瘤クリッピンダと shunt 手術が行わ 九，運動性失語症のみ残して回復しえた。

\section{症例 3：51才，男性，前交通動脈瘤}

1980年 4 月10日, 意識消失在䜀为近医一入院し，2日 後に当科へ転科した，入院時 Grade III の状態であり， その日0) CT scan で大譄縦裂, 雨侧 Sylvius 裂に沿っ て広沉な high density 在認妨たが，脑室の搪大はなかっ た (Fig. 5(A)). 出血 3 日日の脳血管写で前交通動脈瘤が 認められたが血管禁維の所見はなかった。この症例の出 血 3 日目加的頭蓋内压の記録吕 Fig. 6 亿示之机る。初 期には基本圷は約 $20 \mathrm{mmHg}$ と高く，頻回の顽蓋内压变 動在認めていたが，5 日目に至り意識状態の低下ととも

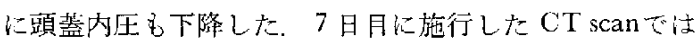
脳室系の拡大もなく low density b認めていない(Fig. 5 (Bi)．このときの脳血管写で全般性戀緶が観察された。 この状態は約 4 日間繶き，次第に意識レベルは上昇し た。碩蓋内圧は低然として低かったが, Fig. 6 の 日日, 10日目の記録でみられるよ5に圧波の間歇的出現がみら れるようになった，14月目のCT scanでは脳公系の搪 大が認められて怙り (Fig. 5(C))，买の後のCT $\mathrm{Ccan} の$

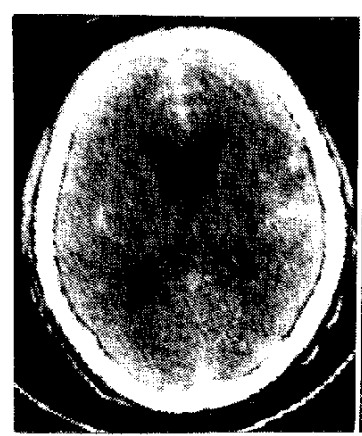

(A)

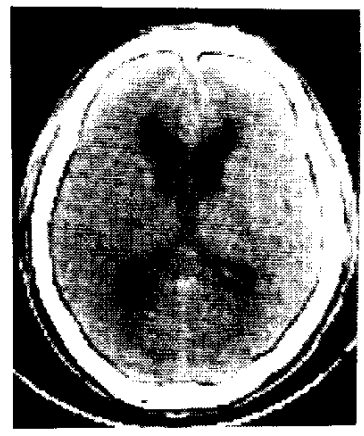

(C)

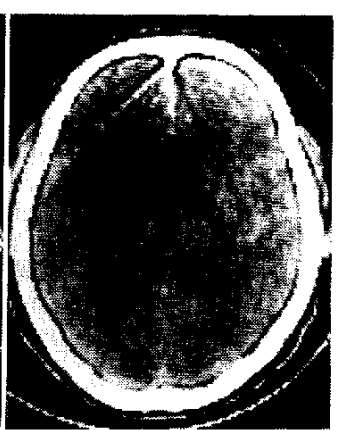

(B)
Fig. 5 51-ycar-old man, anterior communicating aneurysm. CT scans 2 days (A), 7 days (B) and 14 days (C) after the subarachnoid hemorrhage. (A) shows high density at the longitudinal and Sylvian fissures. There is no enlargement of the ventricular system in (A) and (B), whcreas (C) shows moderately dilated ventricles.

経過観察で脳公应大注進行性であった。

木例は出血20日日に動脈瘤クリッピングが施行された が，痴呆状態の堌覀，尿头禁が出現したため shunt 手術 在行い，その後の経過悢良好であった。

3 例の小括：以上の 3 例は出血後の早期加ら比較的長 时間頭篮内圧の記録を行ったものであるが，うち2 例 (症例 1，2）注急性期の高い頭葈内圧が続いた後, 正 常圧水頭症，あるいは乞の淮備状態に移行したのに奶

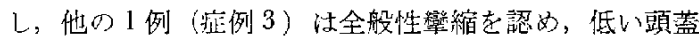
内庄が続いたにも加かわらず徐々に腷室拡大をきたし， 正常任水頭症淁行した。

\section{3. 正常圧水頭症およびその準備状態における頭盖内圧 のパターン}

今回の椧索で頭蓋内压の連続記録は，正常圧水頭症淮 備状態の26例, 定型的正常圧水頭症の17例について行わ 九た。 

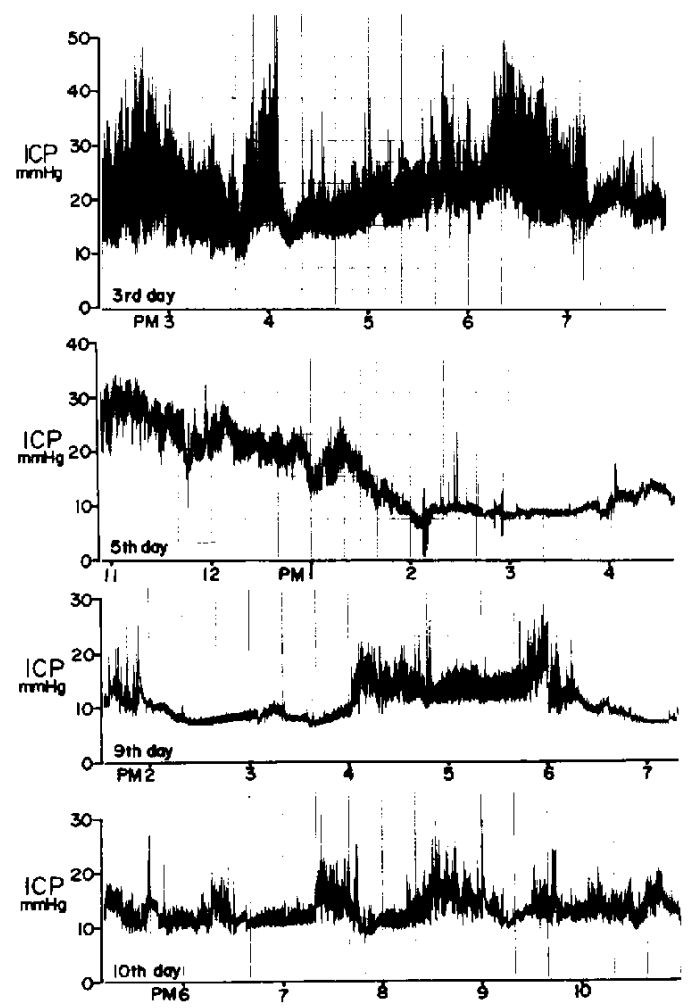

Fig. 6 ICP recording of the same palient as in Fig. 5. High lcvels of ICP with marked fluctuations were seen on the 3rd day and they are replaced by a low and flat ICP pattern on the 5 th day. The carotid angiogram at this time showed a diffuse cercbral vasospasm. Low levels of ICP with pressure variations were seen on the 9 th and 10 th day. CT scan at this stage showed moderately dilated ventricles.

Fig. 7 沬40\%，男性，前交通動脈瘤，出血15，16日目 の術前に打ける頭蓋内圧の記録である。象性期に文られ るような頉回の頭蓋内圧変動けた上えばFig，2に括讨る 7 日日，Fig. 4 に扔汀万 5 日目) は著しく減少し，持続 $5 \sim 10$ 分，振幅 $20 \sim 30 \mathrm{mmHg}$ のプラトウ波様土波が頻 回に出現している。本例の場合，䫓蓋内压に招け石基本 生注 $30 \mathrm{mmHg}$ 前後亡高く，正常圧水頭症準龦状態と考 えたものである。

この症例に拈ける圧波出現の詳細圭ポりグラフにより 検索すると，Fig. 8はFig. 7のAの時期に执けるもので 更万が, Chcyne-Stokes 型呼吸に対応して頭蓋内压に拉 けるB波が連続しているとき，持続の长い呼吸抑制期か 出現し，压変動の持続むこれ几対応して長くなっている ものがみりている、才なわち、このよらな形で持続の 長くなった压波はB波の亜型とも双杂しうる。
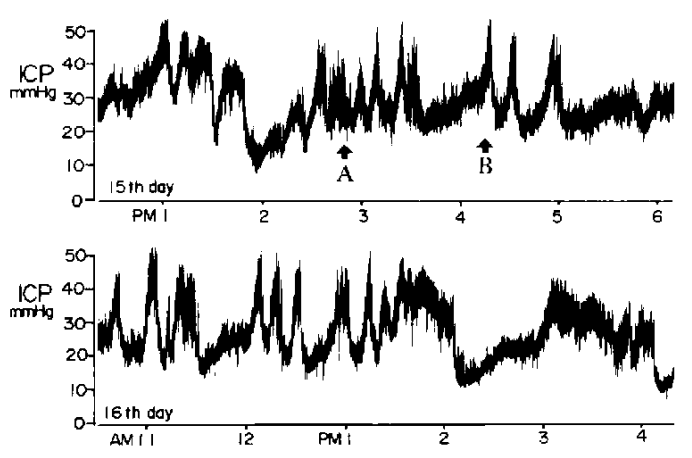

Fig. 7 40-ycar-old man, anterior communicating aneurysm. ICP recording on the 15 th and 16 th day after the subarachnoid hemorrhage. Moderatcly clevated ICP with plateau waves are secn. This is considered as an ICP recording of the pre-normal pressure hydrocephalus state.

一オ，Fig. 9は Fig. 700 B 0時期に扔けるボリグるム ミあるが，非定型的 Cheync-Stokes 型呼吸に一致した頭

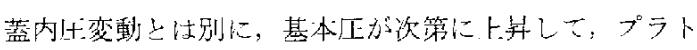

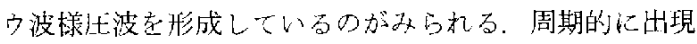

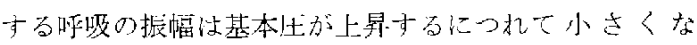
引，抑制在5十ている。全身血巫法周期性呼吸出現時， 一過性上并索示小か，基本圧の上显に対しては変化して

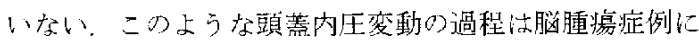
みる定型的プラトり波に似ているか，振幅住小さく，持 続古短いの引゙特徴といえる。

この症例で観察した非定型的なB波やプフトウ波注，

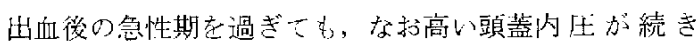
(15 20 mmHg 以上), CT scan, cisternography たo obstructive communicating hydrocephalus の所見を示した 全例に哂的的た。

Fig. 10 は41才, 奴性. 脳底動脈瘤(上小脑㽖脈分岐部) 破裂28日目の頭蓋内正記録でする。本例仙血後25日 間近医で安静を保った後当科人紹介されたが，痴朵，

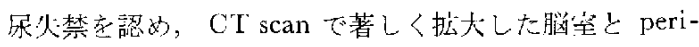

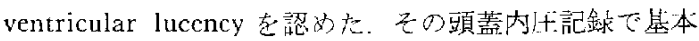
压は15 mmHg 前後と低いが，40 $50 \mathrm{mmHg}$ に達引る

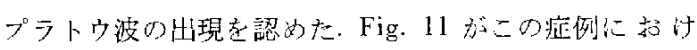
るプラトウ波山現時のポリグラムである。压波出現時，

著しい呼吸の抑制上俆脈認めるな゙，全身血压沬泟とん ど変化していない。

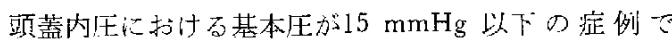
はこのほかに症例2の15日目の記録でみられるような B波のみ代群発しているる0も好った。

是型的正常圧水頭症の条件をそな文，その頭蓋内压連 

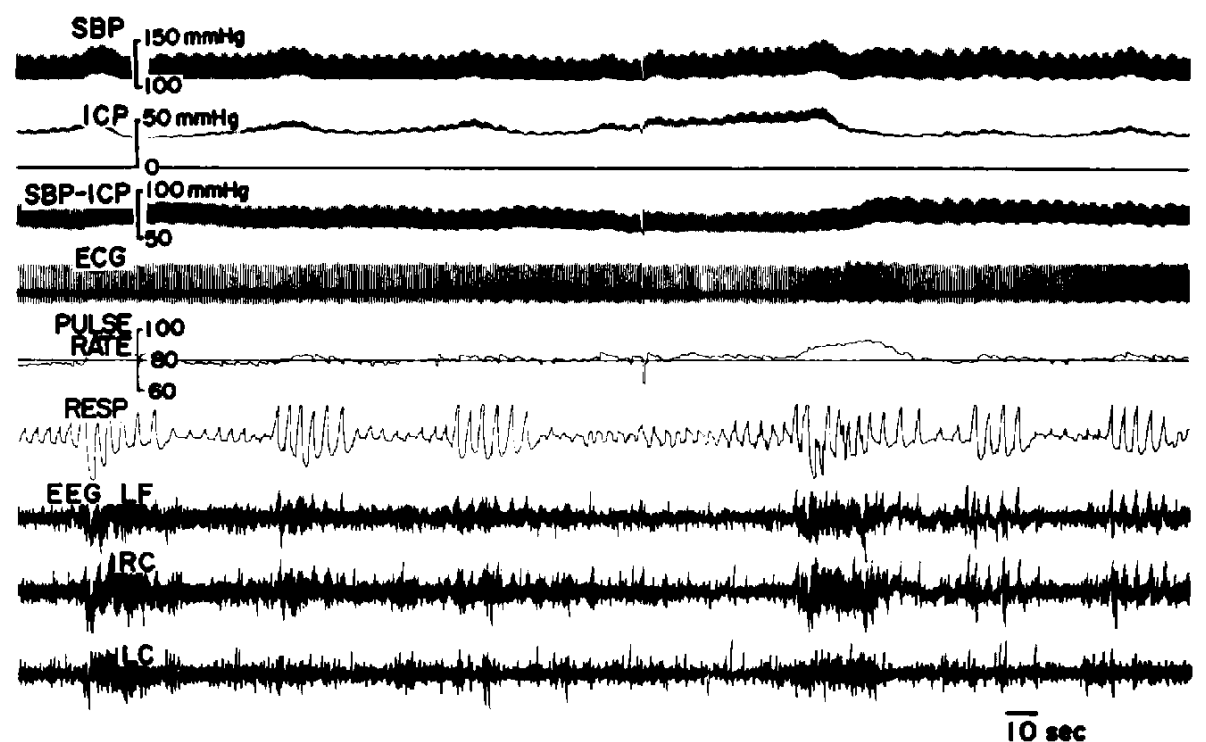

Fig. 8 Polygraphic recording at point A shown in Fig. 7. Atypical B-waves of a long duration are seen. It coincides with long apneustic phase of Cheyne-Stokes respiration.

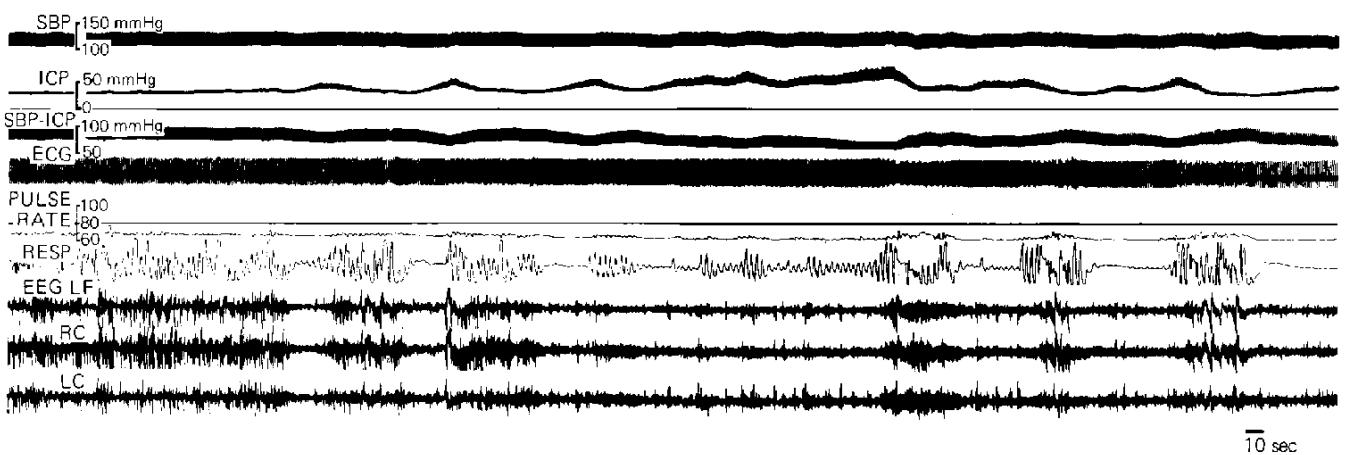

Fig. 9 Polygraphic recording at point B shown in Fig. 7. Transient increase of ICP (plateau wave type) is seen. B-waves arc supcrimposed upon this transient ICP increase.

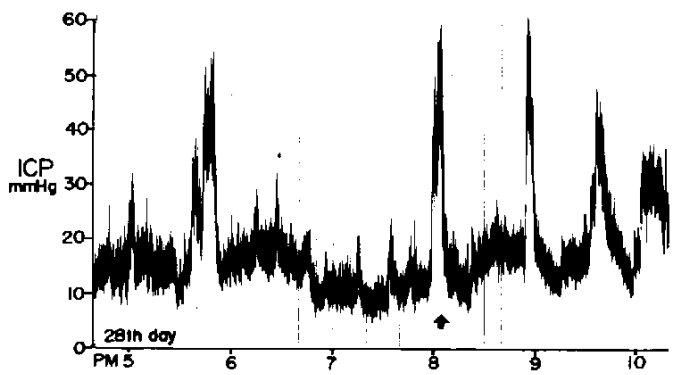

Fig. 10 41-year-old woman, basilar artery aneurysm. ICP rccording on the 28th day after the subarachnoid hemorrhage. Low levels of ICP with plateau waves arc seen. C'I scan at this time showed dilated ventricles with periventricular lucency.
続記録におらてプラトウ波やB波などの压波を諮めたも

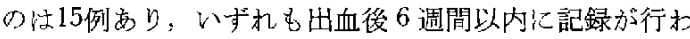
孔衣。

Fig. 12 :53才,女性. 前交通動派瘤, 出血後 6 力月目 に記録されたすのである，頭蓋内压は15 mmHg 前後で 単調なパターンが続き，死波の出現はない。このような 頭蓋内圧のハターンは 2 例に認められて施り, shunt 手 術が行われたが症状の改善は得られなかった。

\section{4. 正常圧水頭症の発生時期}

出血後の早期加ら頭蓋内压荲記録しえた 3 例について みると, 症例 1 は少なくとも15病日以後, 症例 2 は15病 日目。症例 3 注14病日昌に正常圧水頭症加発生してい 子. 


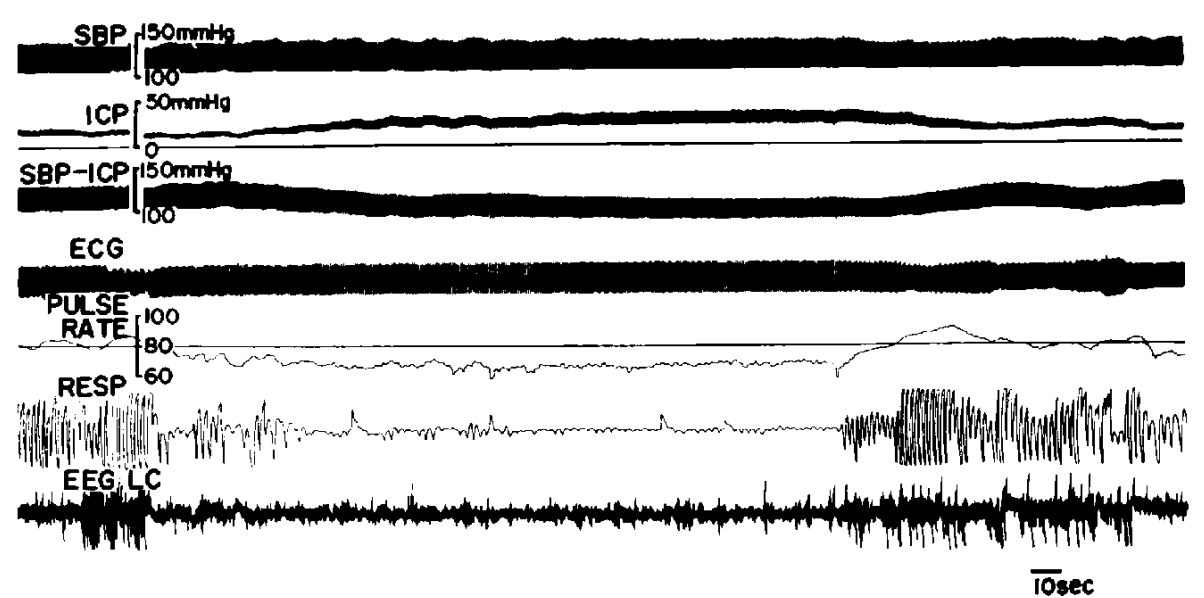

Fig. 11 Polygraphic recording at the point (arrow) shown in Fig. 10. There was no rise in systcmic blood pressure (SBP), whereas bradycardia and hyperventilation developed during the plateau wave phase.

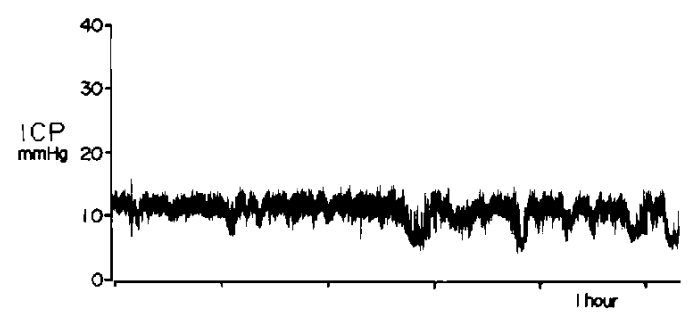

Fig. 12 53-ycar-old woman, anterior communicating aneurysm. ICP recording 6 months after the subarachnoid hemorrhage. A low and flat ICP pattern is seen.

今回の検索に执いて，定型的正常圧水頭症の診断のも とに shunt 手術老行った17例中15例方，出血後 3 週間以 上在経過していた。一方，正常圧水頭症淮備状態の診断 のもとに手術を施行したものは出秃後 2〜4週の間であ ot.

\section{5. 正常圧水頭症発生前後における脳血流の変化}

正常厈水頭症発生㷙後に扝いて平均眇血流测定老 15 例 に計25区施行した（Table 1). 出血後の急性期において は 9 例儿施行さ㧈, その平均膊血流量江 $42.9 \mathrm{~m} / / 100 \mathrm{gr} /$ minで女った。この場合, 重症度分類で Grade III 6 例, Grade IV 3例テあり，それぞれの平均脳血流量は47.2 $\mathrm{m} l / 100 \mathrm{gr} / \mathrm{min}, 34.3 \mathrm{ml} / 100 \mathrm{gr} / \mathrm{min}$ と重症度が谁む注 ど低い值が得られた。

一方，正常生水项症淮㒉状態で注6 例について検索さ 机，乙の平均脳血流量は35. $1 \mathrm{~m} / / 100 \mathrm{gr} / \mathrm{min}$ と, 急性期 と比较して低下の傾向を示した，また，定型的正常压水 影症と判定された10例について，その頭蓋内圧連続記録 でプラトウ波むるいはB波などの压波を認めた8例の壮

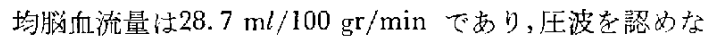

Table 1 Cercbral blood flow in 15 subarachnoid hemorrhage patients

Mcan cerebral blood flow (ml/100 grimin)

\begin{tabular}{|c|c|c|c|c|c|c|}
\hline \multirow[b]{2}{*}{ No. } & \multirow[b]{2}{*}{$\begin{array}{l}\text { Agc, } \\
\text { Sex }\end{array}$} & \multirow[b]{2}{*}{$\begin{array}{l}\text { Site of } \\
\text { aneurysm }\end{array}$} & \multirow[b]{2}{*}{$\begin{array}{l}\text { Acute } \\
\text { stage } \\
\text { (Clinical } \\
\text { grade) }\end{array}$} & \multirow[b]{2}{*}{$\begin{array}{l}\text { Pre- } \\
\text { NPH } \\
\text { state }\end{array}$} & \multicolumn{2}{|c|}{ NPH } \\
\hline & & & & & $\begin{array}{l}\text { Pres- } \\
\text { sure } \\
\text { waves } \\
(+)\end{array}$ & $\begin{array}{c}\text { Pres- } \\
\text { sure } \\
\text { waves } \\
(-)\end{array}$ \\
\hline 1. & $54 \mathrm{~F}$ & $\mathrm{IC}-\mathrm{PC}$ & $36.2($ TV $)$ & & 30.1 & \\
\hline 2. & $56 \mathrm{~F}$ & $\mathrm{AC}$ & $33.8(\mathrm{IV})$ & 27.2 & & \\
\hline 3. & $48 \mathrm{~F}$ & Basilar & $54.9($ III $)$ & & 27.6 & \\
\hline 4. & $63 \mathrm{M}$ & $\mathrm{AC}$ & $32.8(\mathrm{IV})$ & & 30.5 & \\
\hline 5. & $45 \mathrm{~F}$ & $\mathrm{AC}$ & $45.4($ III $)$ & & 30.3 & \\
\hline 6. & $62 \mathrm{~F}$ & IC & & 31.9 & 26.8 & \\
\hline 7. & $52 \mathrm{~F}$ & Vertebral & $47.2(\mathrm{III})$ & 40.4 & & \\
\hline 8. & $59 F$ & $\mathrm{AC}$ & $44.6(\mathrm{III})$ & 35.8 & & \\
\hline 9. & $71 \mathrm{~F}$ & $\mathrm{MC}$ & & & 26.5 & \\
\hline 10 & $48 \mathrm{~F}$ & $\mathrm{AC}$ & $46.3($ III $)$ & 37.4 & & \\
\hline 11. & $53 \mathrm{~F}$ & $\mathrm{AC}$ & & & 27.6 & \\
\hline 12. & $32 \mathrm{M}$ & $\mathrm{AC}$ & $44.9($ III $)$ & & 29.8 & \\
\hline 13. & $62 \mathrm{M}$ & $\mathrm{AC}$ & & & & 24.3 \\
\hline 14. & $62 \mathrm{~F}$ & IC & & & & 23.3 \\
\hline 15. & $63 \mathrm{M}$ & $\mathrm{AC}$ & & 38.0 & & \\
\hline & (Mt & & 42.9 & 35.1 & 28.7 & 23.8 \\
\hline
\end{tabular}

NPH: normal pressure hydrocephalus, pre-NPH state: pre-normal pressure hydrocephalus state, IC: internal carotid, PC: posterior communicating, AC: anterior communicating, MC: middle cerebral, Clinical grade: by Hunt and Hess (1968). 
かった2例のそれは23.8 $\mathrm{m} / 100 \mathrm{gr} / \mathrm{min}$ と著しい低值 走示した。

\section{Shunt 手術の効果について}

頭蓋内压の検索老行った43例全例に対し shunt 手術 行わ扎た。の結果心は正常圧水頭症準備状態の26例法 全例有效でるった。方，定型的正常圧水頭症17例中12 例は有効であったが，5例は症状の改善をみなかった。 これらの症例の内訳では，2 例が頭蓋内圧の連続記録に 挍いて压波の出現をみず出血後 6 力月以上老経過したる のであり，2 例法血管擎縮の合併による広汎な low density 热めたもの，1例が巨大な脳内血腫を合併した むのであった.

\section{N 考按}

马モ膜下出血後の早期江坮ける急性水頭症の登生頻度 は，報告者によりかなりのばらつきがある。たとえば水 上ら ${ }^{111}$ は約 $10 \%$, Raimondi と Torres ${ }^{15)}$ は $10.9 \%$, Folz $^{13}$

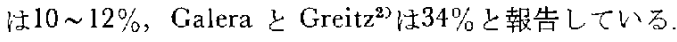
これらの急性期水頙症は $1 \sim 2$ 週間の経過で消腿してい く名のもあるが，な水頭症の状態が残存し，媨室拉大 が進行して shunt 手術在要とするものす少なくない

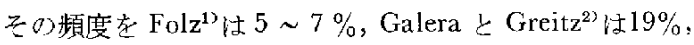
Pertuiset $b^{14}$ は23.1\%と報告している. Vapalahti $ら^{193}$ は手術待期群にお汀る水頭症発生が14\%であったのに対 し，手背群では $19 \%$ と高く，手術孛水頭症発生の促進要 因として重視しているが，Yaşargil $ら^{203}$ 江術前症例 $15 \%$ ， 術後症例 $9 \%$ に水頭症発生索双たこと加，手術は関俰 がなかったと述べている，茂野ら ${ }^{163}$ は早期手術を行った 差例の正常圧水頭症の発生率注26\%で，晚期手術例にお ける発生率16\%よりはるかに高率であったと報告してい

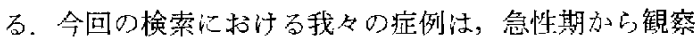
しえた症例に限られているため，急性水頭症の発生覑度 は特に検討しなか力たが，終局的に shunt 手術が必要で あったものは17.4\%でありこの5ち直達手術前に水影 症の存在起認わたりのが9.7\%, 手術後に確認したものが $7.7 \%$ でった。これまでの報告や我々の結果加ら，クモ 膜下出血後の慢性水頭炡発生頻度は扩上そ10 20\%の䦎 と考えられ，また，諸家の報告に打汀急性水頭症の発 生頻度加10 34\%であることから，その半数以上が慢性 水頭症纪移行するものと推定される。

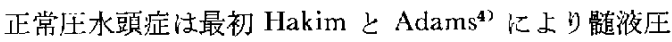
加正常䇺囲内にあるものとして報告された。しかし， Symon らは頭蓋内圧連続記録に拉いて正常圧でない時 期のあることを認め、この病態を cpisodically raised pressure hydrocephalus と烀ぶのが適切であると述ぶ183，

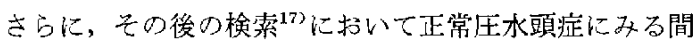
歇的頭盖内圧上昇は，Lundberg ${ }^{103} の$ 報告したプラトウ波 より振幅も小さく持続も短いが，プラトウ波に似た在波 およびB波であり，頭蓋内圧連続記録においてこのよう な圧波が記錄されれば shunt 手術は有效であると報告 し，頭蓋内压連続記録の重要性索主張した，今回の検索 において，全例に頭蓋内压の連続記録が行われたが，正

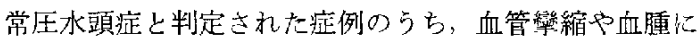
上る広汎な脳損傷を合併したものを除けば，圧波を認め た症例は寸べて shunt 于術が有效であった。一方，正常 压水頭症準備状態にある症例では，全例にプラトウ波や B 波在認ぬ，時間の経過とともに正常圧水頭症に移行寸 るものであるが, shunt 手術は有效でありっこの上5に早 い時期に積極的な治療を行うことは早期回復の面加ら重 要と荐えられる

正常在水頭症の完成時期に関して，今回の検索，一部 には 2 週後にすでに正常压水頭症に移行したものb方っ たが，大多数の抒例は 3 週以上党経過して診断されてい る. 茂野ら ${ }^{16)}$ は出血後 $3 \sim 4$ 週が平均的なところと述心゙ て扔り，我々もこのへえの時期が妥当と考える。

クモ膜下出血急性期に扰いは，通常プラトウ波は認

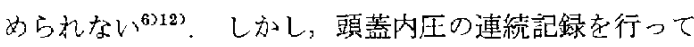
いると，正常圧水頭症やその準備状態に移行する症例で は，しばしば出血後の10日目者過ぎる頃より持続の長い 非定型的 B 波やプラトウ波様圧波が記録されるようにな り，慢性水頭症への移行を示昗する所見と考无られた

正常圧水頭症に括ける脳室拡大の機序に関し Hakim

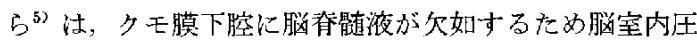
が上景し，その压は脳実質を介して直接頭蓋骨に及び， subdural stress となって腷室壁にさらに強い圧を及ぼす ことが大きな原因と考えている。しかしPertuiset ら Vapalahti ら ${ }^{197}$ はこの上らな原因のほかに媨血管揧縮 が発生した場合，脳血流が低下して脳室拡大をきたすこ ともあると考えている。今回の頭意内压を急性期加放 録しえた 3 例のらち，2例は高い頭蓋内圧が続いた後正 常压水頭症一移行したが，他の1例（症例 3）は蕱樎発 生後，低い状態の頭蓋内压加続いた後，正常压水頭症江 移行した．血管戀縮索合併寸るような症例では，basal cistern などに多量の血液を認めるものが多く，したがっ

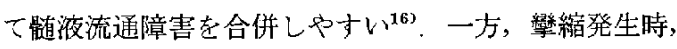
しばしば頭蓋内压が低下する症例のあることも知られて

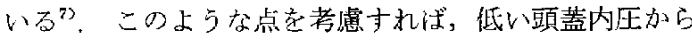
正常压水頭症八移行する症例もありらると思われる。儿 かし，今回の検索においてこのような経過を示したの はこの症例のみであり，今後の検討が必要である. 
脳血流測定による検索では，急性期 症 例 で $42.9 \mathrm{ml}$ $100 \mathrm{gr} / \mathrm{min}$ とかなり高い值を示したのに対し,正常圧水 頭症淮備状態では35. $1 \mathrm{ml} / 100 \mathrm{gr} / \mathrm{min}$ と低下の傾问圭 示し，正常圧水頭症に移行した症例で梳圧波を認める 群, 認めない群でそれぞれ28.7, $23.8 \mathrm{ml} / 100 \mathrm{gr} / \mathrm{min}$ と 頭蓋内圧加正常化しているにもか加わらず，著しい低俏 を示した，正常圧水頭症に㧍ける脸血流低下の機序はな お明らかでないが，脳室拡大による脳室表面積の増加が

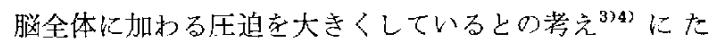
てば，頭蓋内圧に招ける絶刘值怟低くても相対的頭蓋内 压亩進の起こっていることが考えられ，それが兴血流低 下を引き起こしているとも考えられる。

正常压水頭症の状態が長期間絸くことは低い脳血流の 状態が長く続くことを意味し，結果として譄に何らかの 器質的変化药生ずる可能性が考充ら扎る，クモ膜下山血 後”， あるいはその他の原因による水頭症 ${ }^{13}$ に挔いて，

しばしば側脳室上衣下を走る皮質春路路に退行性変化が 起こったり，あるいは慮血性壊死のみられることが報告 されている。今回の検索に打いて出血後 6 力月以上を経 過し，頭蓋内圧記録で压波り出現をみなかった2例では shunt 手術が無効であったが，このことは媨に不可逆性 病要の生した可能性在䏡唆与る。

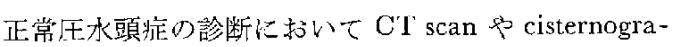
phy の所見が重視されがちであるが，頭蓋内庄連続記録

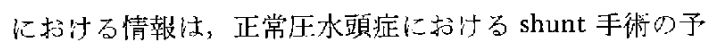
後判定の資料を提供引る上とむに，より早期に慢性水頭

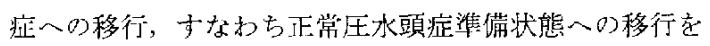
䛦断するために主重要でるる。このことは，患者の早期 回復，むるい梳不可逆性媨障害の発生をさけるという立 場につながるものと考えられる。

我々は shunt 手術適応次ついて，次のよらな枀件走考 えている。(1)郘术症状が進行性であること（2)経特的 CT $\operatorname{scan}$ に书ける進行性腹室掋大，(3)頭蓋内圧連続記録 においてブラトウ波やB波圭認める，(4)出血後3週以上 交経過しているなどである。以上の条件の1 つとして3

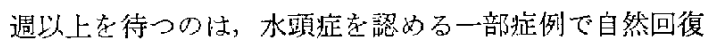

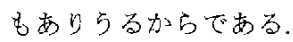

\section{$\mathrm{V}$ ¿ $め$}

1. 夕壬膜下出血後に正常汢办㖽症に移行した 43 例 (術前24例, 術後19例) について, 頭蓋内圧連続記録: CT scan, cisternography, 媨血流測定などを行い検索し t.

2. 頭蓋内压連続記録に㧍いて，基本圧方 $15 \sim 20$ $\mathrm{mmHg}$ 以上を示寸多の正常圧水頭症準備状態, 15
$\mathrm{mmHg}$ 以下にあるもの定型的正常圧水頭症として区 分し検討した。

3. 定型的正常圧水頭症群では，压波を認めないす の，寸な゙広沉な脱損傷の存在するものでは shunt 手術 は無効であった。

4. 正常死水頭症準備状態では，頭㥺内圧記録でプラ トウ波，B波などの圧波老認め，全例 shunt 手術が有効 であった。

5. 脳血流は, 正常圧水頭症潐備状態，定型的正常圧 水頭症のいずれの群においても低下しており，特に㾏波 萑認めない群では低值で尔った。

\section{文献}

1) Fol7, E. L.: Discussion. I Neurosurg 20: 10471048,1963

2) Galera, R. G. \& Grejtz, T.: Hydrocephalus in the adult secondary to the rupture of intracranial arterial aneurysms. $J$ Neurosurg 32:634641,1970

3) Greitz, T.: Cercbral blood flow in occult hydroccphalus studied with angiography and the Xenon 133 clearance method. Acta Radiol [Diagn] 8: 376-384, 1969

4) Hakim, S. \& Adams, R. D.: The special clinical problem of symptomatic hydrocephalus with normal cerebrospinal fluid pressure: Observation on cerebrospinal fluid hydrodynamics. I Neurol Sci 2: 307-327, 1965

5) Hakim, S., Venegas, J. G. \& Burton, J. D.: The physics of the cranial cavity, hydrocephalus and normal pressure hydrocephalus: Mechanical intcrpretation and mathematical model. Surg Neurol 5: 187-210, 1976

6) Hayashi, M., Marukawa, S., Fujil, H., Kitano, T., Kobayasit, H. \& Yamamoto, S.: Intracranial hypertension in patients with ruptured intracranial aneurysm. $J$ Neurosurg 46 : $584-590,1977$

7) Hayashi, M., Marukawa, S., Fujil, H., Kitano, T., Kobayashi, H., Munemoto, S. \& YAMATo, S.: Intracranial pressure in patients with diffuse cerebral arterial spasm following ruptured intracranial aneurysms. Acta Neurochir $44: 81-95,1978$

8) Hunt, W. E. \& Hess, R. M.; Surgical risks as related to the time of intervention in the repair of intracranial ancurysms. $J$ Neurosurg 28: 1419,1968

9) Kibler r, R. F., Couch, R. S. C. \& Crompton, M. R.: Hydrocephalus in the adult following spontaneous subarachnoid haemorrhage. Brain 84: 45-61, 1961 
10) Lundberg, N.: Continuous recording and control of ventricular fluid pressure in neurosurgical practice. Acta Psychiatr Neurol Scand 36 [Suppl 149]: 1-193, 1960

11）水上公贸，金 弘，荒本五郎，美原 博： 脱動脈瘤破裂後の水頭症. 媨外 4:33-41，1976

12) Nornes, H. \& Magnaes, B.: Intracranial pressure in patients with ruptured saccular ancurysm. I Neurosurg 36: 537-542, 1972

13) Penfield, W. \& Elvidge, A. R.: Hydrocephalus and the atrophy of cerebral compression. pp 1203-1217, In Pcnfield, W.(ed): Cytology and Cellular Pathology of the Nervous System, P. B. Hoeber, Inc., New York, 1932

14) Pertuiset, B., Hout'teville, J. P., George, B. \& Margent, P.: Dilatation ventriculaire précoce et hydrocéphalie consecutives à la rupture d'anévrysmes artériels sus-tentoriels. Neurochirurgia 15: 113-126, 1972

15) Raimondi, A. J. \& Torres, H.: Acute hydroccphalus as a complication of subarachnoid hemorrhage. Surg Neurol 1:23-26, 1973

16)茂野卓, 省藤 夏, 有竹康一, 金子美紀子,
美馬達夫，估々木勝，長島 正，渡辺英寿，野 口 信, 谷島健生, 佐野圭司：破裂脑動脈瘤急 性期手術後の水頭症. 神経外科 19 : 529-535, 1979

17) Symon, L. \& Dorsch, N. W. C.: Use of longterm intracranial pressure measurement to assess hydrocephalic patients prior to shunt surgery. $J$ Neurosurg 42: 258-273, 1975

18) Symon, L., Dorsch, N. W. C. \& Stephens, R. J.: Pressure waves in so-called low pressure hydrocephalus. Lancet 2: 1291-I292, 1972

19) Vapalahti, M., Nieminen, U. \& Kari, K.: Incidence of hydrocephalus and increased ventricular fluid pressure in patients with ruptured supratentorial aneurysms. pp 135-138, In Beks, J. W. F., Bosch, D. A. \& Brock, M. (eds): Intracranial Pressure III, Springer-Verlag, Berlin-Hcidelberg-New York, 1976

20) Yaşargil, M. G., Yonekawa, Y., Zumstein, B. \& StahL, H. J.: Hydrocephalus following spontaneous subarachnoid hemorrhage. $J$ Neurosurg 39: 474-479, 1973 